\title{
Det middelalderlige Kollegiatkapitel i Haderslev og dets embedsområde, Barved syssels provsti
}

\section{Af $H$. V. Gregersen}

Den nordligste del af det gamle bispedømme Slesvig - området mellem Kolding fjord og Genner bugt - indtog i middelalderen en særstilling i kirkelig henseende. Sognene inden for dette område hørte ikke til Slesvig domkapitels embedsområde, men under et eget præsteskab, det såkaldte kollegiatkapitel i Haderslev. ' Forskellen mellem de to arter af kapitler bestod først og fremmest $i$, at et domkapitel også varetog bispedømmets almindelige administration. Syd for Elben findes (eller fandtes) der adskillige kollegiatkapitler. Nord herfor var Eutin et eget kollegiatkapitel i forhold til domkapitlet i Lübeck, og i København samledes et kollegiatkapitel ved Vor Frue kirke som et særligt præsteskab i forhold til domkapitlet i Roskilde. Men disse tre kollegiatkapitler, Haderslev, Eutin og København, var også de eneste inden for det landområde, som efter Ribe-mødet $\mathrm{i} 1460$ blev regeret af medlemmer af det oldenburgske kongehus.

Haderslev kollegiatkapitels embedsområde kaldtes Præpositura Barwith Sysæl, på nutidsdansk Barved syssels provsti. Allerede $\mathrm{i}$ denne navngivning er der noget bemærkelsesværdigt. I Nørrejylland følger stiftsgrænserne overalt de gamle skel mellem syslerne, der tør antages at være administrative enheder med hævd meget langt tilbage i tiden. I Sønderjylland derimod går afgrænsningen mellem Ribe og Slesvig stifter tværs over gamle sysselskel. Ikke blot Barved syssel, men også Ellum syssel er delt mellem de to bispedømmer.

Afgrænsningen tværs igennem Ellum syssel følger forskellige herredsskel, og det kunne tyde på, at denne afgrænsning er foretaget på et ret tidligt tidspunkt. Antagelig er det dette skel, der er næunt af Adam af Bremen, hvor han fortæller, at Toke, "hertug af Vinland " (»dux Winlandensis«), der var fader til Ribes magtfulde biskop gennem 40 år, den i 1043 afdøde Odinkar, som fædrenearv overlod sin søn en tredjedel af sit land. Der kan naturligvis ikke være tale om Vinland i Amerika, end- 
sige Vendsyssel, men opfatter man Adams »Vinland « som en fejlskrivning for "Sinland «, nævnt i de frankiske rigsannaler og i Ottars rejseberetning (sidstnævnte sted: "Sillende«) som betegnelse for Sønderjylland, er der tale om Tokes jarledømme. Denne antagelse støttes af Odinkar-slægtens tilknytning til Sønderjylland i vikingetiden, bevidnet af, at kong Gnupas dronning Asfrid, næunt på runestenene fra Vedelspang ved Slesvig-Hedeby, var en Odinkar-datter. Er denne opfattelse rigtig, svarer det meget godt til, at biskop Odinkar af Ribe har haft herredømmet over den nordvestlige del af Sønderjylland, ja måske endda over hele området nordvest for en linje fra Genner bugt til Vidåens munding. ${ }^{2}$ Noget kunne nemlig tyde på, at stiftsskellet tværs igennem Barved syssel stammer fra en senere tid og skal ses i forbindelse med oprettelsen af kollegiatkapitlet i Haderslev.

Intet andet sted inden for det gamle danske rige er en stiftsgrænse trukket på tværs af alle eksisterende verdslige administrationsområder, intet andet sted er en grænsedragning tilsyneladende mere vilkårlig end den mellem Ribe stift og den nordligste del af Slesvig bispedømme, ${ }^{3}$ det område, der var Haderslev kollegiatkapitels embedsområde, Barved syssels provsti. Nok hørte Haderslev og Tyrstrup herreder i deres helhed til dette provsti; men herrederne vest herfor var skåret igennem. Fra nord mod syd hørte af Frøs herred kun Skodborg sogn i kirkelig henseende under Haderslev. Af Gram herred hørte de fleste sogne, nemlig Jels, Oksenvad, Sommersted, Maugstrup, Hammelev, Jegerup og Vedsted sogne under Haderslev, og dertil endnu de to øde sogne, Nybøl og Arvad, der begge ophørte at eksistere, da lyngen bredte sig, og den derværende befolkning ikke mere kunne skaffe sig nok til livets opretholdelse, en foreteelse, som man har kaldt »den senmiddelalderlige ødelægning«. Længst imod syd hørte af det gamle Rangstrup herred (i senmiddelalderen delt i Nørre- og Sønder Rangstrup herreder) kun Øster Løgum sogn til Barved syssels provsti. ${ }^{\star}$

Afgrænsningens tilsyneladende vilkårlighed făr mening, når man følger Hærvejens forløb i højmiddelalderen. Det viser sig da, at dette gamle vejforløb mellem Immervad og Vad (vadestedet over Kongeåen umiddelbart vest for Skodborg) overalt ligger på Slesvig bispedømmes grund og dermed inden for Barved syssels provsti. Det var Hugo Matthiessen, der først gjorde denne iagttagelse, ${ }^{5}$ og når man gør sig klart, at der engang eksisterede et særligt Nybøl sogn med en kirke, hvis tomt nu findes ved bebyggelsen Lilholt allerøstligst i Skrydstrup sogn, er denne iagttagelse bekræftet i ét og alt. ${ }^{6}$

Hærvejen mellem Vad ved Skodborg og Immervad findes nogle ste- 




Barved syssels provsti fra Kolding fjord og Kongeden sydpå til Genner bugt. gengivet efter kortet i Quellensammlung d. Ges.f. Schl. = Holst. Geschichte, VI, 1904.

Med stiplet linje er indtegnet Harvejens vestligste forlab, Savsevejen. Prikkerne viser omfanget af de forsvundne sogne, Nybol og Arvad (hvis vestligste dele nu ligger i Skrydstrup og Bevtoft sogne i Ribe stift).

der, bl.a. i 1638 i forbindelse med skellet mellem Skrydstrup og Lilholt det oprindelige stiftsskel - benævnt som Sakservejen (Savsevejen, e Savsvej). ${ }^{7}$ Uden tvivl har vi med denne betegnelse højmiddelalderens navn på Hærvejen. Hærvejen er et senere og egentlig tysk navn, Savsevejen derimod giver god mening som navn for vejen ud af landet ned mod saksernes land, mod Tyskland. ${ }^{8}$ Svarende hertil kaldes i Bjolderup og Uge sogne en afbøjning fra Hærvejen Friservejen (e Frisvej), vejen ud mod Nordfrisland. 
Det tør således antages, at afgrænsningen mellem Ribe og Slesvig stifter vest for Haderslev er sket ud fra et ønske fra Slesvig bispestol om at have rådighedsretten over Hærvejen, højmiddelalderens Sakservej. Kun en sådan opfattelse giver mening, når man sammenligner stiftsgrænsen med forløbet af Hærvejen, vel at mærke i dens oprindelige vestligste forløb.

Hvornår dette skel er blevet trukket, kan der selvsagt kun gisnes om. Påfaldende er det imidlertid, at man her har ladet et vejforløb være normgivende for afgrænsningen, mens opdelingen af Ellum syssel følger gamle herredsskel. Det kunne tyde på, at delingen af Barved syssel er foretaget på et senere tidspunkt, og at oprettelsen af et kollegiatkapitel ved Vor Frue kirke i Haderslev skal ses i sammenhæng med denne grænsedragning.

Første gang kollegiatkapitlet i Haderslev nævnes, er i 1273, da biskop Bonde af Slesvig overlod det bispetienden fra Aller sogn i Tyrstrup herred.' Tienden skulle deles i fire lige store dele mellem kantoren, diakonen og subdiakonen, samt klokkeren. Den sidste fjerdedel skulle gå til anskaffelse af vokslys. Ordet »kapitel« nævnes ikke i brevet; men opremsningen af gejstlige titler vidner om, at der i det nævnte år eksisterede et organiseret præstesamfund ved Vor Frue kirke. Nogle år senere fik kapitlet af samme biskop Bonde også indtægterne af Hoptrup kirke. ${ }^{10}$

I årene kort før tildelingen af indtægter til kapitlet var Haderslev Vor Frue kirke blevet ombygget til en såkaldt »halle-kirke«. Man antager, at denne udvidelse af teglstenskirken, der 0.1250 havde afløst en tidligere kvaderstenskirke, er sket i årene efter $1260,{ }^{11}$ og man tør vel derfor antage, at udvidelsen så kort tid efter hænger sammen med oprettelsen af kollegiatkapitlet. Det større præsteskab krævede mere plads.

Men hvad skyldtes oprettelsen af kollegiatkapitlet i Haderslev? Med sikkerhed lader et sådant spørgsmål sig ikke besvare. Dertil er det bevarede kildemateriale for pauvert. Et er imidlertid sikkert: det kan ikke skyldes sproglige forhold, eftersom det dansk-sønderjyske folkesprog o. 1260 strakte sig helt sydpå til Danevirke. Måske ligger der en antydning $\mathrm{i}$ betegnelsen $»$ Barved syssels provsti $\ll$. Ligesom der længere mod syd var et »Ellum syssels provsti« som betegnelse for den del af syslet, der hørte til Slesvig, er der også for Barved syssels vedkommende en antydning af, at der er tale om en oprindelig enhed, der er blevet delt mellem to gejstlige instanser.

Spørgsmålet er da, om der i årene efter 1260 (med udvidelsen af Vor 
Frue kirke i Haderslev) og i tiden før 1273 (med den første antydning af et særligt præsteskab i denne by) har fundet begivenheder sted, der kunne tjene til at forklare, at der skabtes et særligt Barved syssels provsti, og tanken falder da i den forbindelse hen på den danske kirkekamp, der netop i dette tidsrum førte til et væbnet opgør, ikke blot mellem konge og ærkebiskop, men også mellem konge og hertug, samt mellem Ribe og Slesvig bispestol.

Kirkekampens ydre hovedpunkter er i al korthed disse: I 1256 havde ærkebiskop Jacob Erlandsen bandlyst kong Christoffer I, 1259 var kongen pludselig død i Ribe (ifølge sagnet som følge af en forgiftning under nadverens indtagelse). I 1264 havde Rom i Clemens IV fået en ny pave, der utvetydigt støttede Danmarks ærkebiskop, og først i 1271 fandt den lange strid mellem kongemagt og ærkebiskop sin afslutning ved forhandlinger i Rom. I 1274 døde Jacob Erlandsen på vej hjem til Danmark.

Men den lange strid fik også sin særlige udløber syd for Kongeåen i form af et opgør mellem de to grene af Valdemar Sejrs efterslægt. Christoffers søn, den endnu mindreårige Erik Klipping, repræsenteredes af enkedronning Margrethe Sambiria, kaldt Sprænghest, og hendes modstander var Abels søn, hertug Erik I af Sønderjylland. Først efter enkedronning Margrethes nederlag i 1261 på Lohe hede nord for Rendsburg var Christoffer-slægten rede til - indtil videre - at anerkende Abelslægtens herredømme over Sønderjylland.

Under kampene mellem de to grene af det gamle kongehus var biskop Esger af Ribe på kongens side og dermed også i strid med sin ærkebiskop, mens biskop Bonde fandt støtte hos hertug Erik I. Blandt begivenhederne i denne strid kan nævnes, at hertug Erik i 1261 tog domkapitlet i Slesvig i sit værn, ${ }^{12}$ og at han i 1265 ødelagde biskop Esgers faste hus i Møgeltønder. ${ }^{13}$ Endnu i samme år, den 22. september 1265, nåede de to parter dog frem til et forlig, og hertug Erik meddelte derefter alle i Ribe stift, der var under hans herredømme, at han nu også tog kirken i Ribe i sin beskyttelse. ${ }^{14}$

Fra det følgende år, 1266, kendes nogle forhandlinger mellem Erik Klipping og biskop Bonde, repræsenteret af hhv. kongens kansler og af provsten og ærkedegnen i Slesvig. ${ }^{15}$ De skal have fundet sted i Haderslev og drejer sig om nogle "skipæn«, nemlig Kær herred syd for Tønder og tre andre i Sønderjylland. De to slesvigske krønikeskrivere, Hieronymus og Paul Cypræus, har begge givet et referat af disse forhandlinger, men de er uklart formulerede, f.eks. opfatter Cypræus'erne ikke »skipæn« som herred, men som »skibe«. Navnene på de tre andre her- 
reder kendes ikke; men det er påfaldende, at Barved syssels provsti netop omfatter tre herreder, nemlig Gram, Tyrstrup og Haderslev (samt sognene Skodborg og Øster Løgum), og forhandlingerne fandt jo netop sted i Haderslev.

Mere kan der ikke løftes af sløret over hine års tildragelser. Ser man imidlertid på et kort med de middelalderlige stiftsgrænser, synes det helt naturligt, at Ribe stift, der omfattede Jelling og Almind sysler med byerne Vejle og Kolding, også engang har haft Barved syssels provsti med Haderslev. Bevises kan denne dristige tese ikke; men den åbner for en forklaring på, hvorfor Haderslev engang i 1260'erne fik sit eget præsteskab og derved udskilte sig fra de sydligere liggende egne, der var en del af Slesvig domkapitels embedsområde.

Kollegiatkapitlets organisation og beføjelser kendes fra dets statutter, der i 1309 blev bekræftet af biskop Johann Bokholt af Slesvig. ${ }^{16}$ Allerede i 2. artikel siges det, at provsten over Barved syssels provsti hverken havde myndighed over kannikerne eller plads i kapitlet. Han residerede ved domkirken i Slesvig. Derimod var ifølge 3. artikel kantorens stemme afgørende, og han havde sæde øverst i koret, mens de øvrige kanniker havde plads efter den rækkefølge, deres ansættelse angav. Det var kantoren (artikel 4), der ledede kirken og koret og så til, at det gik rigtigt til med læsning og sang.

I forhold til et domkapitel var kollegiatkapitlets beføjelser mere begrænsede. Måske netop takket være dette kunne kannikerne ofre mere tid på undervisningsvæsenet. I hvert fald blev det af afgørende betydning, da nationalsprogene i løbet af 1300-årene vandt større og større betydning i forhold til latinen. Det hedder nemlig i statutternes 13. artikel, at den, der var født i Barved syssels provsti og optaget i præstestanden, skulle tjene to år i Haderslev kirkes kor og underholdes af midler fra Slesvig domkapitel. I domkapitlets statutter, der kendes fra 1352, krævedes parallelt hertil, at unge fra domkapitlets embedsområde, der var under præsteuddannelse, skulle tjene i to år ved domkirken i Slesvig. ${ }^{17}$ Der opstod derved inden for Slesvig stift et uddannelsesskel for præsteviede (og det vil i virkeligheden sige for alle med højere uddannelse), og grænsen gik mellem Øster Løgum og Løjt sogne.

Dette skel udviklede sig som følge af den særlige udvikling i Sønderjylland til et slags kulturelt skel. I årene under biskop Johann Bokholt (1308-1331) - den første holstener på Slesvig bispestol - og da navnlig i tiden efter 1325, da grev Gerhard III af Rendsburg (Gert, 》den kullede 
greve«) udstrakte sit herredømme over hele Sønderjylland og optrådte som Danmarks »administrator«, ændredes sammensætningen af Slesvig domkapitel på afgørende vis. En optælling af navnene på kannikerne her fra 1325 til 1350 viser, ${ }^{18}$ at Slesvig domkapitel i løbet af dette kvarte århundrede blev et overvejende tysk kapitel. Dette fik til følge, at middelalderens plattyske kancellisprog, således som det kendes fra hanseaternes og snart efter også fra danske kongers dokumenter og breve, blev det nationalsprog, som anvendtes under præsteuddannelsen, så snart man forlod latinen. Plattysk blev derved det sprog, som unge skrivekyndige fra dansk-sønderjysktalende hjem i alle sognene mellem Genner bugt og Slien greb til, så snart noget skulle udfærdiges på skrift, eller når noget mere højtideligt, f.eks. det religiøse, skulle udformes i tale. Plattysk blev med andre ord »det højere sprog«, om man vil kultursproget. Det skal lige tilføjes, at dette plattysk var hanseaternes kancellisprog og ikke en af de mange plattyske dialekter. Det her anførte kom også til at gælde nordfriserne på vestkysten af Slesvig domkapitels embedsområde.

Det kom derimod ikke til at gælde for unge præstekandidater fra de sønderjyske sogne, der hørte under Ribe og Odense, d.v.s. fra sognene mellem Kongeåen og Vidåen, samt de alsiske sogne. Ved domkapitlerne $\mathrm{i}$ Ribe og Odense var dansk naturligvis det nationalsprog, der benyttedes, når man forlod de lærdes sprog.

Det er på denne baggrund, at vi i vor tid skal bedømme betydningen af, at der i Haderslev kom et særligt kollegiatkapitel som lærdomscenter for Barved syssels provsti, for i Haderslev indtog det danske sprog ligesom i Ribe og Odense sin helt naturlige plads som det nationalsprog, der anvendtes, når der ikke blev talt latin.

For hertugdømmet Slesvig - som man i 1300-årene efter tysk skik som oftest kaldte Sønderjylland - betød det, at der i senmiddelalderen gik en art kultursprogsgrænse fra Vidåens munding nord om sognene Hostrup, Højst, Ravsted, Rise og Løjt, altså tværs igennem et område, hvor den dansk-sønderjyske dialekt var folkesproget. Hele Sundeved, samt købstaden Sønderborg - de sønderjyske hertugers residensstad indtil 1375 - hørte med til det område, der som en del af det slesvigske domkapitels embedsområde var orienteret $i$ retning af stiftsstaden Slesvig.

Sønderjyllands almindelige politiske udvikling gjorde sit til at understrege og forstærke det plattyske sprogs stilling som »det højere sprog«, som kultursproget. For forståelsen af Sydslesvigs sproglige situation i 
dag blev det således afgørende, at dette område også efter attentatet på Gerhard III i 1340 forblev under de schauenburgske grevers herredømme. Den egentlige kamp om, hvorledes det skulle gå landsdelen som helhed, satte for alvor ind, da schauenburgerne efter Abel-slægtens uddøen og Valdemar Atterdags død i 1375 satte sig i besiddelse af hele Sønderjylland.

Den politiske udvikling skal her kun skitseres. For at vinde tid for sin nordiske politik gav Margrethe I 1386 grev Gerhard VI af det schauenburgske hus hele Sønderjylland som len, men efter hans død i 1404 uden voksne arvinger begyndte dronningen på lidt efter lidt af genvinde herredømmet over grænselandet. Hun havde da forinden i 1397 fået sikret Kalmar-unionen. Hendes bestræbelser førte imidlertid til åben krig fra vinteren $1409 / 10$, og den varede stort set til 1435 . I lange tider udspilledes hovedbegivenhederne i denne krig i strøget mellem Tønder og Flensborg. I 1412 fik dronningen endda herredømmet over Flensborg, hvor borgen Duborg blev den danske kongemagts faste bastion.

For Slesvig stift og dets biskop og domkapitel fik krigshandlingerne vidtgående konsekvenser. I krigens lange år var området fra Flensborg og nordpå unddraget den øverste kirkelige ledelse i Slesvig. Med andre ord: stiftet var sprængt!

Af højgejstligheden i Slesvig var det kun biskoppen, Johannes Skondelev, en franciskaner fra Hessen (der i 1375 af Valdemar Atterdag var blevet gjort til biskop) og hans ærkedegn (archidiakon) Erich Dosenrode, som sluttede sig til den danske kongemagt. Den øvrige del af højgejstligheden med domprovst Heinrich von dem See som den ledende stod derimod på schauenburgernes side.

Som følge af denne splittelse måtte biskoppen og ærkedegnen forlade Slesvig. Kun i det område, der beherskedes af Erik af Pommern, dronning Margrethes efterfølger, havde de sikkerhed for liv og lemmer. Ny ærkedegn i Slesvig blev en af kannikerne, Johann Hauschildt, og da Johannes Skondelev døde i 1421 (og trods krigshandlingerne eller måske posthumt blev begravet i Slesvig domkirke), ${ }^{19}$ valgte domkapitlet Heinrich von dem See til ny biskop over Slesvig. Siden Johann Bokholt var blevet biskop i 1308, havde ærkebiskoppen af Lund ikke haft indflydelse på, hvem der blev udnævnt til biskop af Slesvig; men for den danske kongemagt var domkapitlets ensidige valg af en af schauenburgernes håndgangne mænd naturligvis helt uantagelig. 
For kollegiatkapitlet i Haderslev betød skismaet inden for den slesvigske kirke den helt store chance. De haderslevske kanniker vejrede morgenluft, de indså muligheden af at oprette et eget Haderslev stift med tilhørende domkapitel. Hertil behøvedes en rigtig katedral, og fra året 1410 meldes der om gods og gaver, der gives til kapitlet i Haderslev: 1410 Øsby kirke, ${ }^{20} 1416$ Moltrup, Bjerning, Ảstrup og Grarup. ${ }^{21}$ Dertil kom, at kong Erik i 1415 tog Vor Frue kirke i Haderslev og hele dets kapitel i sit værn. ${ }^{22}$ Endvidere kendes fra årene 1413 til 1440 otte dokumenter, ${ }^{23} \mathrm{i}$ hvilke navngivne adelige og storbønder overdrager kapitlet jordegods. Et par gange nævnes det, at formålet gjaldt kirkens udbygning.

Allerede i 1401 tyder et privilegium fra hertug/greven Gerhard VI på, at man havde påtænkt en udvidelse af kirken i Haderslev; ${ }^{24}$ men hvad der skete i årene 1420-1440, overgik uden tvivl alle hidtidige planer. Efter at Slesvig stift i løbet af årene 1410/12 var blevet sprængt, gjaldt det om at få skabt en rigtig katedral i Haderslev, og byens ledende gejstlige, kantoren Tue Petersen og kanniken Niels Ulfsen, ${ }^{25}$ stilede mod at få kollegiatkapitlet frigjort fra det slesvigske domkapitels indflydelse. Det ses da også af de aktstykker, der i 1421 blev udarbejdet til brug for den kejserlige voldgiftsdom i 1424, hvori Haderslevs Vor Frue kirke omtales som domkirke på lige fod med domkirkerne i Ribe og Slesvig. ${ }^{26}$

På den tid fungerede Vor Frue kirke også som en rigtig domkirke. Da Slesvigs biskop, Johannes Skondelev, var død i 1421, og det slesvigske domkapitel egenmægtigt havde gennemtrumfet valget af domprovst Heinrich von dem See til ny biskop, ${ }^{27}$ var forbindelsen mellem Haderslev og Slesvig blevet afbrudt. Lunds ærkebiskop udnævnte da i $1423^{28}$ som følge af den politiske situation to gejstlige, nemlig Niels Ulfsen fra Haderslev og den flensborgske præst Peter Riggelsen, til at forestå administrationen af de biskoppelige indtægter fra hele den nordlige del af det hidtidige Slesvig stift, der beherskedes af kong Erik. De to gejstlige skal uden tvivl ses som repræsentanter dels fra Barved syssels provsti og dels for det slesvigske domkapitels embedsområde fra Flensborg og nordpå til Løjt, med andre ord et tydeligt vidnesbyrd om, at Slesvig stift var sprængt.

Kirkeretligt set kunne den trufne ordning kun blive et provisorium, og der er antagelig foregået en række forhandlinger mellem Lund og pavestolen og mellem Slesvig og Rom. Resultatet blev, at kurien i 1426 fandt frem til Johannes Skondelevs kongetro ærkedegn, Erich Dosenrode, og udnævnte ham til koadjutor for Slesvigs biskop. ${ }^{29}$ I denne egenskab skulle han forvalte den del af bispedømmet, der beherskedes 


\section{$E_{c c .}$. Cathedralis}

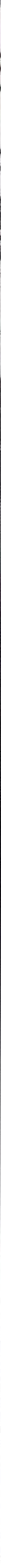

Haderslev Vor Frue kirke, som den så ud i senmiddelalderen og frem til 1627, da kirkens vestlige parti med det store tärn ud mod Apotekergade blev flammernes bytte. Illustrationen er et udsnit i forstorret gengivelse af det byprospekt, der findes $i$ Georg Braunius' store vark fra 1588. Bemark, at Vor Frue kaldes katedralkirke (ecc[lesia] Catedralis). 
af kong Erik. Denne ordning betød, at Slesvig stifts enhed formelt var blevet genoprettet. Ved biskop Heinrich von dem Sees død viste det sig dog atter engang, at modsætningerne ikke var blevet bilagt. Slesvigs domkapitel udnæunte nemlig omgående Claus Wulf, Johann Hauschildts efterfølger som ærkedegn i stiftets sydlige hoveddel, til ny biskop. Også den nye biskop stod schauenburgerne nær, ${ }^{30}$ og kong Erik indsendte derfor i 1434 en klage til konciliet, der var samlet i Basel, hvori han gjorde gældende, at bispevalget i Slesvig i 1429 havde været et indgreb $i$ hans patronatsrettigheder. ${ }^{31}$

Men på det tidspunkt kunne man tage let på kong Eriks klagemål, overflødiggjort som det var blevet på grund af den politisk-militære udvikling. I 1431 havde kongens tropper måttet opgive Flensborg og rømme Duborg, og dermed var kongens nederlag i den årelange kamp om Sønderjylland blevet åbenbar. De fredsforhandlinger, der fandt sted i 1432 og 1435, understregede den engang så stærke kongemagts katastrofale nederlag.

Afslutningen på den lange krig mellem den danske kongemagt og de schauenburgske grever afbrød brat alle det haderslevske kollegiatkapitels højtflyvende planer. Slesvigs biskop, Claus Wulf, var fast besluttet på at gøre en ende på den separatisme, som kollegiatkapitlet havde søgt at fremme i ly af den danske kongemagt. I 1434 hører vi om en udvidelse af kapitlet med to nye kanniker, og de var tyskere med hjemsted $\mathrm{i}$ Breslau og Bremen. ${ }^{32}$ Selv besøgte biskoppen sit stifts nordligste by, lige så snart forholdene muliggjorde det, og han lod en bispegård opføre - ovenikøbet af sten - i nærheden af Vor Frue kirke. ${ }^{33}$ Siden da har Haderslev haft en Bispegade. Det gjaldt ham åbenbart om at vise, at Slesvigs biskop var kommet for at blive! Som retmæssig herre også over Barved syssels provsti ønskede han at sikre stiftets enhed.

Biskop Claus Wulfs resolutte indgriben har sat sig sine varige spor $\mathrm{i}$ det ombygningsarbejde, der siden ca. 1420 havde været i gang i Vor Frue kirke. Arkitekter og bygningshistorikere har altid gjort opmærksom på, ${ }^{34}$ at den højnelse af tværskibet, der efter alt at dømme var forberedt, ikke blev til noget, og at hovedskibets udbygning fra det fornemme gotiske højkor er foregået på en mere beskeden måde. Grunden hertil er uvis; men ser man på den kirkepolitiske situation, der var opstået efter den danske kongemagts opgivelse af Flensborg i 1431, har man en forklaring på, at ombygningsarbejdet er blevet reduceret til det mindst mulige. Heldigvis - således vil alle, der elsker Haderslevs nuværende domkirke sige - var det gotiske højkor skabt, inden Claus 


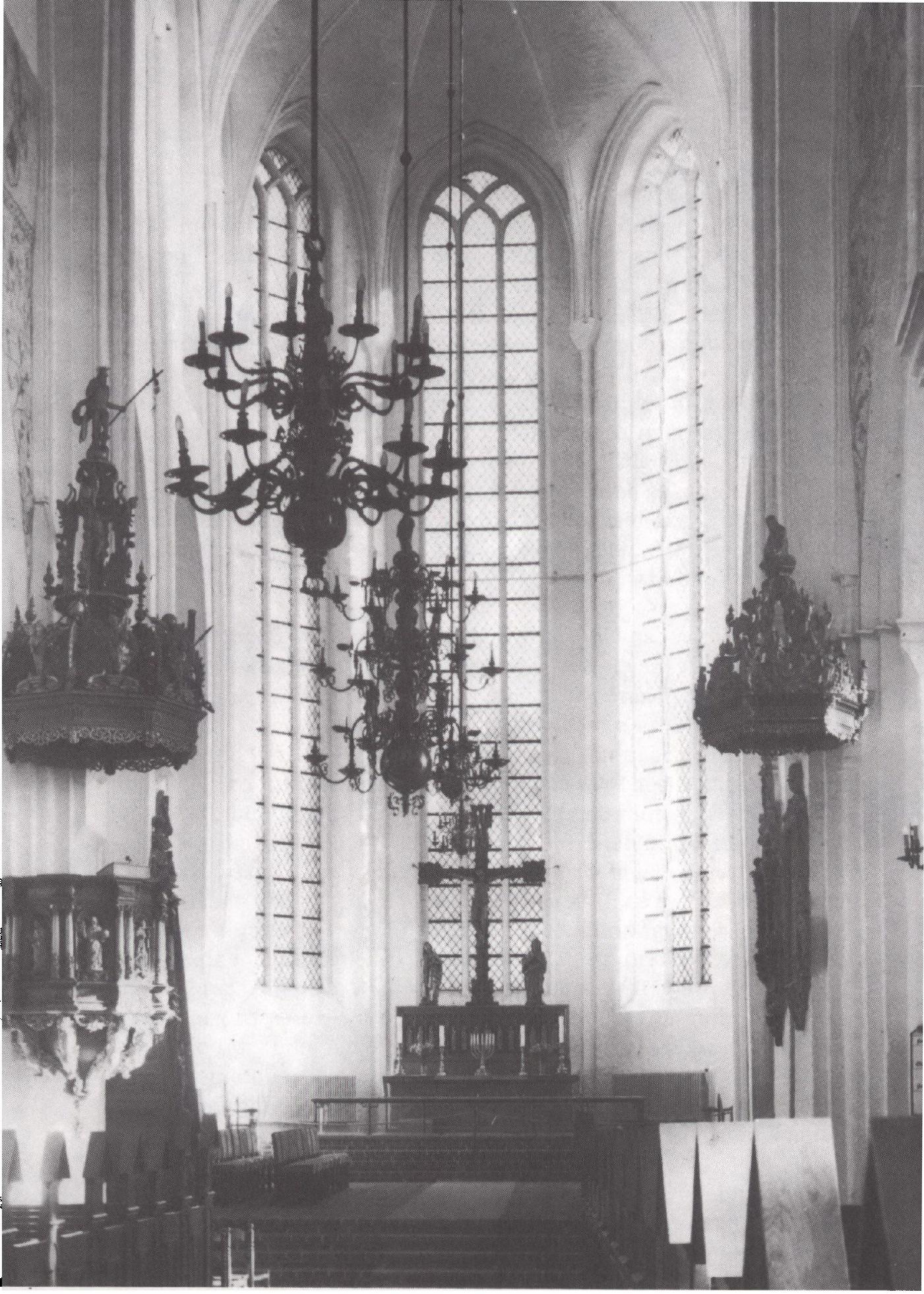


Wulf kom for at bremse det igangværende byggeri. Midtskibet måtte derfor bygges videre i samme højde, og takket være dette lykkedes det bygherrerne - trods modstanden fra Slesvigs biskop - at forlene Vor Frue til Haderslev med et virkeligt katedralpræg.

Det var ikke blot kirkebyggeriet, men også kollegiatkapitlet, der fik den nye politiske situation at føle på allernærmeste hold. Den schauenburgske greve, Adolf VIII, blev efter erobringen af Flensborg i 1431 i året 1440 anerkendt som hertug af Slesvig af Danmarks nye konge, Christoffer af Bayern, og af det danske rigsråd. Det betød, at hertuggrevens administration, ledet af det slesvig-holstenske ridderskab, gjorde det plattyske sprog til øvrighedens sprog overalt i hertugdømmet. Det er i den forbindelse karakteristisk, at Haderslevs borgmester, der hidtil havde udformet sine breve på dansk, efter 1440 gjorde brug af det plattyske skriftsprog. ${ }^{35}$

Dette forhold fik naturligvis også afgørende virkninger for kirkens gudstjenestesprog, selv om den kultursproglige situation, der havde vundet hævd gennem det haderslevske kollegiatkapitels virke ikke lod sig ændre. Som ivrig tilhænger af den kirkelige reformbevægelse, der var kommet i højsædet i Rom efter Baseler konciliet i 1440 med pave Felix $\mathrm{V},{ }^{36}$ sørgede biskop Claus Wulf for at indføre en ordning af prædikesproget, der både tilgodeså menighedens store flertal og den fåtallige overklasse. I 1442 indstiftede han et nyt Helligånds-alter i Vor Frue kirke, ${ }^{37}$ for - som det hedder i indstiftelsesbrevet - »at bortjage splittelsens og vildfarelsens ånd fra Haderslevs indbyggere«. Den nye alterpræst skulle være »summus vicarius«, d.v.s. som den fornemste have rang foran kannikerne, og han skulle prædike på modersmålet alle søndage og ved højtiderne for »at fæstne gudstjenesten i Haderslevs kirke«. Der kan ikke være tvivl, at biskoppen med oprettelsen af det nye præsteembede har ønsket at sikre det danske sprog som gudstjenestesprog for at bringe kirkens budskab ud til byens alt $i$ alt dansktalende befolkning og vel også for at bryde den politiske spænding i borgerskabet, som indstiftelsesbrevets indledning tyder på.

Men det betød ingenlunde, at øvrighedens plattyske sprog var blevet glemt. I 1465 lod biskoppen »efter skik og brug i tyske lande« et særligt lektur indrettet $\mathrm{i}$ kollegiatkapitlet. ${ }^{38}$ Lektoren skulle ugentligt holde

Haderslev domkirkes høje kor er $i$ vor tid det fornemste udtryk for den gotiske bygnings$k u n s t i$ vort land. De tre korvinduer er 15,9 meter høje. Fot. C. Krassél. 

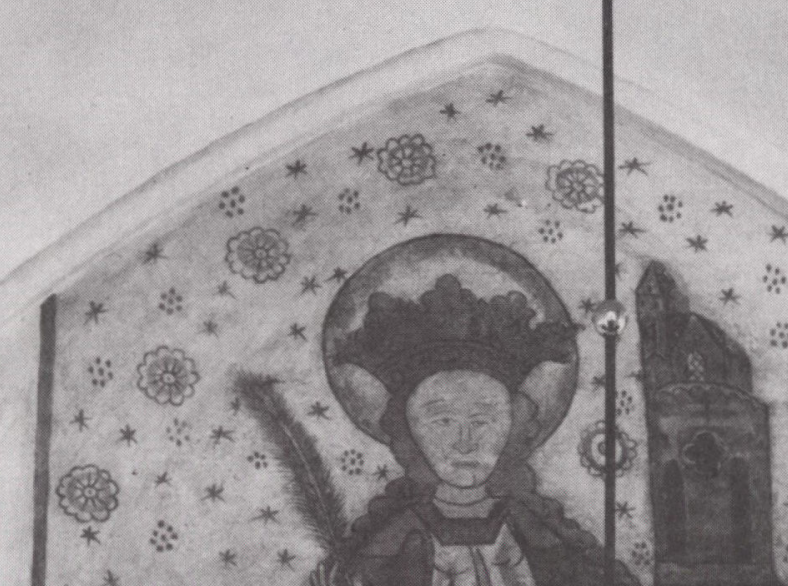

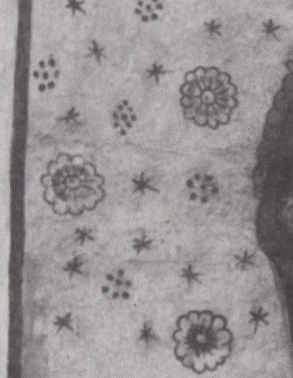

$\cos _{*}^{*} \therefore *^{*} *$

1) 10

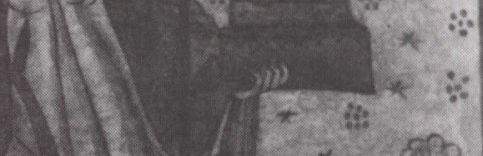
(f) $=1 \times$

$(-3.20 \times 1:$

$1-\operatorname{se} 1 * *\{83$

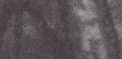

(x) $*$ कs $*$

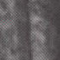

$3^{*} * x *$ $+\cos * 4$ * * * *

* $* * \cos$

* $\ln 3 * *$

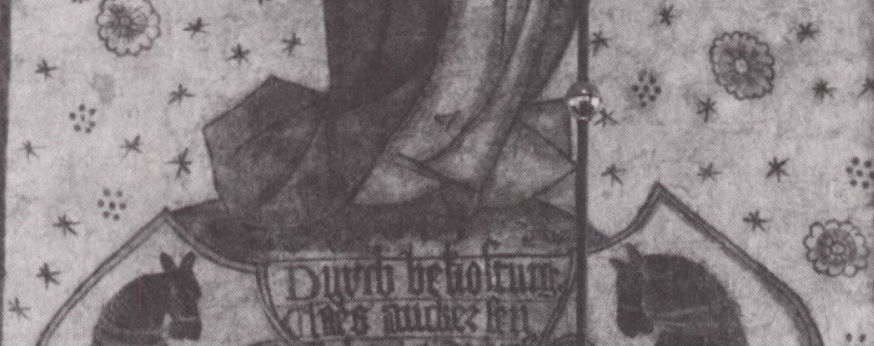

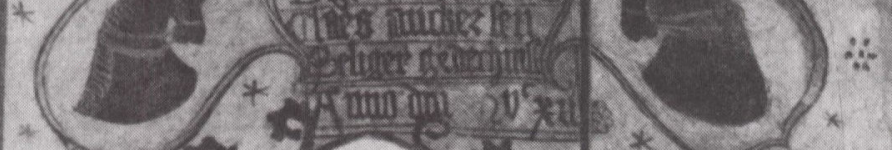

in:
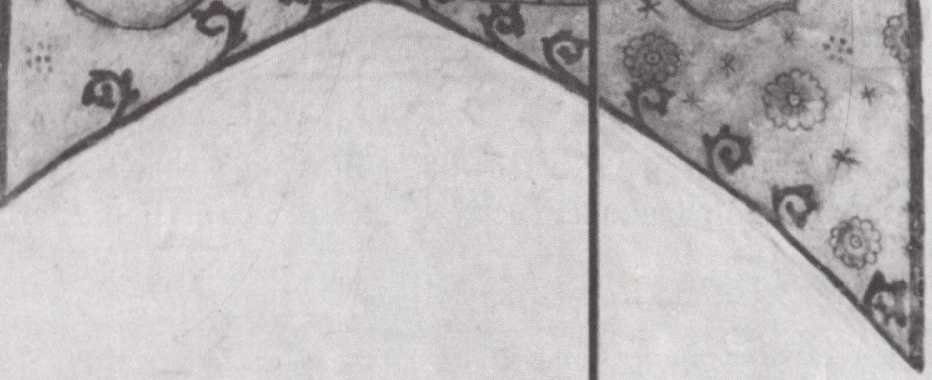
forelæsninger for kannikerne og de vordende præster. "Da vejen til virkelig tro hos præsterne«, hedder det i bispens skrivelse, »beredes gennem studiet af den Hellige Skrift, skulle der arbejdes med Bibel-eksegese« (d.v.s. undervisning i Bibelens tekster). Desuden skulle lektoren holde gudstjenester, når kannikerne var forhindrede, og som udtryk for den betydning, der skulle tillægges det nye embede, havde lektoren plads i koret ved siden af kantoren.

Den første indehaver af dette embede hed Jacob Horstmann, og han har åbenbart været en fremtrædende mand, siden han senere hen blev rektor for universitetet i Rostock. ${ }^{39}$ I sit teologiske virke har han naturligvis anvendt latin, men i sine prædikener må han have benyttet sit plattyske modersmål. Det er på denne baggrund, at man skal forstå den kirkesproglige ordning, som kendes fra tiden efter reformationen, nemlig at provsten og førstepræsten i de fire nordslesvigske købstæder prædikede på tysk (indtil ca. 1600 på plattysk), mens andenpræsten, archidiakonen, prædikede på dansk. Med en afbrydelse i årene mellem de to slesvigske krige (1850 til 1864) gjaldt denne ordning af gudstjenestesproget med rod i senmiddelalderen helt frem til 1920.

Efter 1440 gik også i Nordslesvig den politiske udvikling i tysk retning, og dette ændredes ikke, da Christian I ved Ribe-mødet i 1460 udråbtes til »herre over landene Slesvig og Holsten«. Det var for øvrigt biskop Claus Wulf, der fra Ribes rådhus kundgjorde mødets resultat. Plattysk som gudstjenestesprog i de nordslesvigske købstæder skyldtes et ønske om at imødekomme øvrigheden og den verdslige administrations ledende mænd. Plattysk blev derved også det sprog, som medlemmerne af byernes patriciat ønskede at høre, når de søgte kirken, mens andenpræstens danske prædikener i hovedsagen henvendte sig til det jævnere borgerskab.

Hele denne politisk betingede udvikling kom også til at ramme kollegiatkapitlets sammensætning. Det er helt tydeligt, at der $i$ årene efter 1440 optoges flere og flere kanniker af tysk afstamning i Haderslevs kollegiatkapitel. Hvis ikke reformationens mænd havde opløst romerkirkens kollegiatkapitel, tyder alt på, at det lidt efter lidt ville komme til at skifte nationalitet, ligesom det havde været tilfældet med det slesvigske domkapitel $\mathrm{i}$ årtierne op imod 1350.

Kalkmaleriet af Sct. Barbara i Vor Frues nordre korsideskib. Den plattyske giverinskription fra 1512 vidner om den sprogligt-kulturelle situation, der opstod efter Adolf VIIIs overtagelse af Haderslev i 1440. Fot. Nationalmuseet. 
I 1441 hed kantoren i Haderslev Mikkel Iversen (Michael Ivari), men hans efterfølger, Timme Schmalstedt (Smalstede), var af holstensk adel, og det hedder om ham, at han havde trængt sig ind $i$ embedet. Efter ham hed kantoren Peter Lorenzen (Petrus Laurentii), men efter hans død i 1474 bar kantorerne almindeligvis tyske navne. En fortegnelse over alle de haderslevske kanniker, der kendes fra tiden efter 1474 og frem til reformationen, viser tydeligt, at det tyske islæt vandt overhånd. ${ }^{40}$ Man tør kun gisne, hvilke følger dette efterhånden ville have fået for gudstjenestesproget ude i landsognene.

Et sidste udtryk for ydre glans oplevede kollegiatkapitlet i Haderslev, da en af dets kanniker (allerede nævnt 1506), Johann Wulf, blev provst over Barved syssels provsti i $1517 . .^{41}$ Johann Wulf var i de mellemliggende år jævnligt blevet benyttet $\mathrm{i}$ diplomatiske missioner af kong Hans og hertug Friedrich I, og under den pavelige legat Arcimboldus's ophold i Danmark havde han været en af dennes hjælpere ved salget af afladsbreve. Det er antagelig som belønning for sin indsats på dette felt, at han i 1517 fik tilladelse til at forene sit kanonikat i Haderslev med embedet som provst over Barved syssels provsti. I modsætning til sine forgængere tog han ikke ophold i Slesvig, men forblev i Haderslev, og det lykkedes ham at få sit provsti ophøjet til et særligt prælatur med vidtgående selvstændighed $\mathrm{i}$ forhold til biskoppen og domkapitlet $\mathrm{i}$ Slesvig. På hans tid ansås Vor Frue kirke i Haderslev som kollegiatkirke for at være »en halv domkirke« (på plattysk »halffdhom«), og kapitlet talte da foruden kantoren og lektoren syv kanniker.

Med den unge hertug Christians ankomst til Haderslev i 1525 var det imidlertid slut med den romersk-katolske højgejstlighed, der var knyttet til Vor Frue kirke. Den unge hertug Christian havde som udsending for Christian II og faderen hertug Friedrich I i deres egenskab af samhertuger af Holsten deltaget $i$ det tysk-romerske riges rigsdag $i$ Worms $i$ 1521, og her havde han modtaget et uforglemmeligt indtryk af Martin Luther, denne munkeklædte doktor blandt alle fyrsterepræsentanterne, der havde nægtet at afsværge sit forfatterskab, så længe han ikke ud fra den Hellige Skrift kunne blive overbevist om, at han havde taget fejl.

På grund af sønnens åbenlyse tilslutning til Martin Luthers opfattelse af ret kristendom havde hans fader, den forsigtige Frederik I (konge af Danmark siden 1523), kun turdet overlade ham som underholdsområde den allernordligste del af hertugdømmet Slesvig: Haderslev- og Tørninglen. 


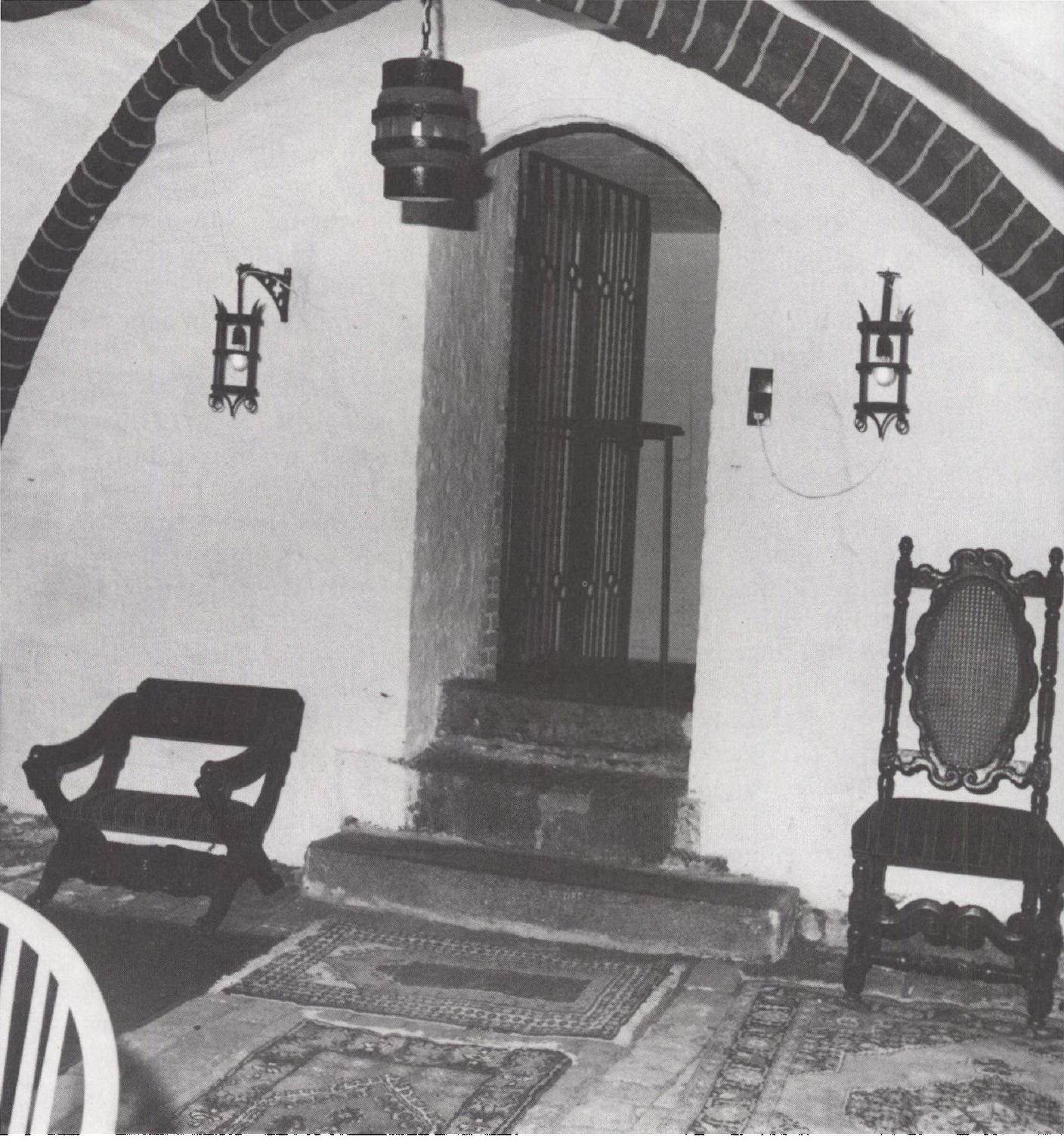

Under forretningen "Osteklokken , Apotekergade 11, der ligger lige over for hovedindgangen til Haderslev domkirke, findes det middelalderlige lektorium, der under reformationen blev Nordens forste evangelisk-lutherske prasteskole. Fot. C. Krassél.

En stor del af det slesvig-holstenske ridderskab var nemlig fortsat gammeldags troende, og mange havde slægtninge inden for højgejstligheden. Slesvigs biskop fra 1507 til sin død i 1541, Gosche Ahlefeldt, tilhørte således ridderskabets på den tid fornemste slægt.

Men hertug Christian havde ungdommens gå-på-mod og utilbøjelig- 
hed til at gå ind på kompromisser. Selv om hans hertugdømme Haderslev-Tørning var nok så lille, var han besluttet på straks at afskaffe det gamle kirkeregimente og erstatte det med lutherdommens fyrstekirke. Han fjernede derfor domprovst Johann Wulf fra embedet ${ }^{42}$ og overtog selv administrationen også af de kirkelige anliggender i sit lilleput-hertugdømme. Et vidnesbyrd herom er et kaldsbrev til en ny sognepræst $\mathrm{i}$ Vonsbæk, udstedt på Haderslevhus den 20. august $1525^{43}$.

Domprovst Johann Wulfs afskedigelse betød, at nu var også kollegiatkapitlets tid udrundet. Dets førende teolog, lektoren Johann Alberdes (eller på dansk: Hans Albertsen), trådte ovenikøbet over til lutherdommen. ${ }^{44}$ Han ønskede dog ikke at blive i den by, hvor han hidtil havde haft sit virke i den gamle kirkes tjeneste, men arbejdede fremover for reformationens sag med titel af hofpræst hos Frederik I, altså samme stillingsbetegnelse, som også Hans Tausen fik, da kongen tog ham i sit værn.

Til at gennemføre reformationsværket i Haderslev benyttede hertug Christian sig derimod af helt nye kræfter. I de første måneder af 1526 ankom fra Martin Luthers hjemegn to betydelige evangeliske teologer, dr. Eberhard Weidensee (Wijdensee) og Johann Wenth (på latin: enten Slavus eller Vandalus, senere som biskop i Ribe: Johan Vandal). Med deres hjælp kom kollegiatkapitlets hidtidige lektorium på den anden side af gaden umiddelbart vest for Vor Frue kirke til at afgive plads for en evangelisk-luthersk præsteskole, der blev søgt fra nær og fjern, endda helt ovre fra Skåne.

Denne præsteskole, kollegiatkapitlets afløser, var intet mindre end et teologisk fakultet, tilmed Nordens ældste evangelisk-lutherske, og det er derfor med god grund, at Haderslev er blevet kaldt »Nordens Wittenberg«.

\section{NOTER OG HENVISNINGER}

1. Den foreliggende afhandling er en noget udvidet gengivelse af mit bidrag til festskriftet "850 Jahre St.-Petri-Dom zu Schleswig. 1134-1984«: Das Kollegiatkapitel Hadersleben (anf. st., s. 221-228). Se også min afh. i Haderslev Stiftsbog, 1973, s. 1226: Haderslev Stift i Middelalderen.

2. Adam af Bremen: De hamburgske Erkebispers Historie og Nordens Beskrivelse. Oversat af Carsten L. Henrichsen, 1968, s. 113. Opfattelsen af, at der er tale om en fejlskrivning, skyldes Vilhelm Marstrand i hans »Aabenraa«, 1933, s. 41; jvf. Sønderjyske Årbøger, 1983, s. 21 (note 17). - I Haderslev Stiftsbog, 1976, s. 9-18, og i Die Heimat 84, 1977, s. 80-87, har Troels Fink foreslået, at stiftsafgrænsningen er blevet aftalt i forbindelse med mødet i 1025 mellem Knud den Store og kejser Konrad. 
3. Tore Nyberg: Grenzen erzählen Geschichte (Zeitschrift d. Ges. f. Schl.-H. Geschichte 107, 1982, s. 15-36).

4. H.N.A. Jensen: Bispedømmet Slesvigs gamle Omfang og Inddeling (Annaler $\mathrm{f}$. Nord. Oldkyndighed og Historie, 1849, s. 332-362); Plattysk i Sønderjylland, 1974, s. 100 (note 253).

5. Hugo Matthiessen: Hærvejen, 3. udg., s. 12-14.

6. H. V. Gregersen: Forsvundne kirker langs med Hærvejen (Sønderjysk Månedsskrift, 1974, s. 237-247); sm.: Plattysk i Sønderjylland, 1974, s. 100.

7. Præsteindberetninger til Ole Worm, I, s. 277: "Sauffsewei, den atskiller fra huerandre Hadersleff proustij och Riber sticht«. Tolkningen af vejnavnet som Sakservej, se: Sønderjyske Stednavne, II, Haderslev Amt, s. 467, 692.

8. Som følge af den senmiddelalderlige ødelægning fulgte det store nord-sydgående Hærvejs-strøg stadig mere østligt gående forløb, indtil fjordbyerne Kolding og Haderslev i slutningen af middelalderen trak trafikken helt over til sig. Det sidstnævnte vejstykke (fra Kolding over Haderslev til Immervad) kaldes gerne Oksevejen, og det var i brug, da Johannes Mejer omkring 1640 tegnede sit kort over Haderslev østeramt. Han gjorde da opmærksom pd, at Hærvejen oprindelig havde haft et mere direkte nordgående forløb fra Vojens og skrev derfor på sit kort "Rechte Heerweg« om Hærvejens rettelige forløb. Uden navns angivelse aftegner Mejer også Pottervejens forløb vesten om Abkær mose, men Savsevejens endnu ældre vejføring mellem Over og Neder Jerstal og mellem Nybøl (Lilholt) og Skrydstrup kender han ikke. Han har ábenbart glemt at opsøge sognepræsten i Skrydstrup, jvf. note 7. Se iøvrigt: Henrik Becker-Christensen: Hærvejen i Sønderjylland, 1981; Bjørn Svensson: Fra Hærvej til Motorvej, 1984.

9. Diplomatarium Danicum (Danmarks Riges Breve), 2. rk., II, nr. 219.

10. DD (DRB), 2. rk., III, nr. 274.

11. W. Güttel: Die Marienkirche in Hadersleben, 1935, s. 27; Danmarks Kirker, Haderslev Amt, s. $58 \mathrm{f}$.

12. DD (DRB), 2. rk., I, nr. 339.

13. Niels Skyum-Nielsen: Kirkekampen i Danmark 1241-1290, 1963, 1971, s. 227.

14. DD (DRB), 2. rk., I, nr. 494. Se også: DD (DRB), 2. rk., II, nr. 39.

15. DD (DRB), 2.rk., II, nr. 49. Ribe stifts omfang i middelalderen kendes fra "Ribe Oldemoder «, men denne oversigt stammer først fra ca. 1340 og siger derfor intet om de ændringer, der måske er sket for Haderslev-egnens vedkommende.

16. DD (DRB) 2. rk., VII, nr. 178; K. J. Jensen: Haderslev Mariekirke (Slesvigs delte Bispedømme, 1949, s. 247-283).

17. Constitutiones capituli Slesvicensis, $\$ 38$ (trykt: Klaus Harms: Das Domkapitel zu Schleswig 1914, s. 167).

18. Optællingen er foretaget i: Plattysk i Sønderjylland, s. 90-92.

19. Die Kunstdenkmäler der Stadt Schleswig, II, 1966, s. 505.

20. Diplomatarium Collegii Canonicorum Hadersleviensium. Aktstykker til Oplysning om Kannikecollegiet i Haderslev før Reformationen, udg. C.M.A. Matthiesen i Aarsberetninger for Det Kgl. Geheime-Archiv, II, 1856, nr. 6.

21. E. Pontoppidan: Den Danske Atlas, VII, s. 127. Begrundelsen for en ændring af árstallet er givet i: Plattysk i Sønderjylland, s. 157 (note 431).

22. Dipl Coll Can Had, nr. 11.

23. Plattysk i Sønderjylland, s. 158, med kildehenvisninger.

24. Dipl Coll Can Had, nr. 4. 
25. Dipl Coll Can Had, nr. 13, 14.

26. »de Dome to Sleswiik, to Ripe vnde to Hadersleff« (Antislesvigsholstenske Fragmenter $13,1848-51$, s. 120.

27. Acta Pontificum Danica (APD) II, nr. 1385, 1387, 1388.

28. Diplomatarium Flensborgense, I, 1865, nr. 94; E. J. Westphalen: Monumenta inedita, III, 1743, s. 308 f. (her: Figolphi fejlagtigt for Rigolphi, Riggelsen).

29. APD, II, nr. 1431. Udnævnelsen har antagelig kostet Erich Dosenrode livet, idet han formodes omkommet under kampen om Flensborg i 1431, se: C. Nyrop: Danmarks gamle Gilde- og Lavsskraaer, I, 1895, s. 607.

30. Repertorium Diplomaticum Regni Danici Mediævalis, 1. rk., III, nr. 6432.

31. APD, III, nr. 1725.

32. APD, III, nr. 1734, 1735.

33. Quellen zur Geschichte des Bistums Schleswig (Quellensammlung d. Ges. f. Schl.H. Geschichte, VI, 1904), s. 244.

34. W. Güttel: Die Marienkirche in Hadersleben, 1935, s. 31; Danmarks Kirker, Haderslev Amt, s. $81 \mathrm{f}$.

35. Plattysk i Sønderjylland, s. 202 f. (med en forklaring på de tre undtagelser, der kendes).

36. Tore Nyberg: Plattysk i Sønderjylland (oppositionsindlæg), i: Historie, ny rk., IX, s. 222-241.

37. Dipl Coll Can Had, nr. 24; Plattysk i Sønderjylland, s. $220 \mathrm{ff}$.

38. Dipl Coll Can Had, nr. 40; APD, III, nr. 2386. - I Danmark kendtes sådanne lektorembeder ikke.

39. Schleswig-Holstein-Lauenburgische Urkundensammlung, IV, nr. 67. Se også: Th. O. Achelis: Deutsche und dänische Gottesdienste im Herzogtum Schleswig (Schriften des Vereins f. Schleswig-Holst. Kirchengeschichte, 2. rk., X, I, 1949, s. 81); sm.: Tausend Jahre der Stifter Ripen und Schleswig (smstds., X, 2, 1950, s. 131).

40. Plattysk i Sønderjylland, s. 225-230.

41. APD, V, nr. 4062; Dipl Coll Can Had, nr. 51, 52.

42. Georg Boethius: Einbericht vnde verkleringe etc. (LA. Haderslev provstearkiv, nr. 533; trykt: Kirkehistoriske Samlinger, 2. rk., II, s. 265-285).

43. Th. O. Achelis: Det ældste Kaldsbrev i Norden (Sønderjyske Aarbøger, 1925, s. 147 152).

44. H. F. Rørdam: Hofprædikanten M. Johan Albertsen (Kirkehistoriske Samlinger, 2. rk., II, s. 290-298). 